\title{
THE CROATIAN HEALTH INSURANCE FUND DOES NOT RECOGNIZE DIFFERENCES IN THE COST OF DIFFERENT TREATMENTS FOR REVISION TOTAL HIP ARTHROPLASTY
}

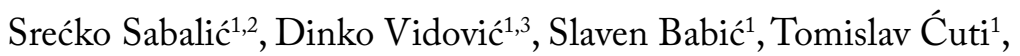 \\ Domagoj Gajski ${ }^{3,4,6}$, Krešimir Rotim ${ }^{4,5,6}$ and Dejan Blažević ${ }^{1,4}$ \\ ${ }^{1}$ Department of Traumatology, Sestre milosrdnice University Hospital Centre, Zagreb, Croatia; \\ ${ }^{2}$ School of Medicine, University of Split, Split, Croatia; \\ ${ }^{3}$ School of Dental Medicine, University of Zagreb, Zagreb, Croatia; \\ ${ }^{4}$ University of Applied Health Sciences, Zagreb, Croatia; \\ ${ }^{5}$ School of Medicine, Josip Juraj Strossmayer University of Osijek, Osijek, Croatia; \\ ${ }^{6}$ Department of Neurosurgery, Sestre milosrdnice University Hospital Centre, Zagreb, Croatia
}

\begin{abstract}
SUMMARY - In recent years, there has been increased interest in the cost of treatment for revision interventions for hip and knee prostheses. In all publications so far, the authors note the high cost of treatment for revision interventions, especially if infection is present. The aim of this study was to compare the cost of treatment and health insurance reimbursements between revision total hip arthroplasty (THA) for infection and revision for aseptic indications (aseptic instability and periprosthetic fracture). Hospital data on 168 patients having undergone revision THA between 2010 and 2018 at the Department of Traumatology, Sestre milosrdnice University Hospital Centre from Zagreb were analyzed. Financial data were collected from the Hospital Information System. Financial analysis included total cost per patient, Croatian Health Insurance Fund reimbursements, cost of implants, and length of hospital stay. The difference between the mean total cost per patient and the mean Croatian Health Insurance Fund reimbursements was $-262.83 €(-6.08 \%)$ for aseptic instability, $-1694.94 €$ $(-17.25 \%)$ for infection and $-916.49 €(-17.33 \%)$ for periprosthetic fracture. The Croatian Health Insurance Fund does not recognize differences in the cost of revision THA for aseptic instability, infection and periprosthetic fracture. Health insurance reimbursement is inadequate for centers that offer revision hip surgery.
\end{abstract}

Key words: Revision total hip arthroplasty; Infection; Periprosthetic fracture; Aseptic instability; Financial analysis

\section{Introduction}

The most common reasons for revision total joint arthroplasty published in the literature are instability with or without aseptic loosening, infection and periprosthetic fracture ${ }^{1-3}$. In recent years, due to the

Correspondence to: Asst. Prof. Srećko Sabalic, MD, PhD, Department of Traumatology, Sestre milosrdnice University Hospital Centre, Draškovićeva 19, HR-10000 Zagreb, Croatia

E-mail: ssabalic@gmail.com

Received February 18, 2020, accepted April 5, 2020 high cost of treatment for revision prosthetic surgery, there has been increased interest in this issue ${ }^{4-7}$, especially as health insurance institutions are not considered to cover treatment costs ${ }^{8}$. In Croatia, the cost of treatment for revision surgery of hip prosthesis has not been analyzed so far, which also holds for payment of the Croatian health insurance for revision hip surgery, including aseptic or septic instability, which needs revision after total hip prostheses and/or periprosthetic hip fractures. 


\section{Methods}

We analyzed hospital data on 168 patients having undergone revision total hip arthroplasty (THA) between 2010 and 2018 at the Department of Traumatology, Sestre milosrdnice University Hospital Centre from Zagreb. Financial data were collected from the Hospital Information System. Financial analysis included total cost per patient, Croatian Health Insurance Fund reimbursements, cost of implants, and length of hospital stay. Patients were divided into three groups according to indications for revision THA, as follows: aseptic instability, infection and periprosthetic fracture (which requires treatment with some kind of revision type of hip prosthesis). On statistical analysis, Student's t-test at $95 \%$ confidence level $(\mathrm{p}<0.05)$ was used. The cost of treatment, reimbursement and cost of implants were expressed in $€$.

\section{Results}

During the 2010-2018 period, 168 patients underwent revision THA. Their mean age was 70.82 (range 47-92, SD 9.73) years. There were 73 (43.5\%) male and 95 (56.5\%) female patients. Indications for surgery were aseptic loosening and instability in 89 (52.9\%), infection in $35(20.8 \%)$ and periprosthetic fracture in 44 (26.1\%) cases (Fig. 1).

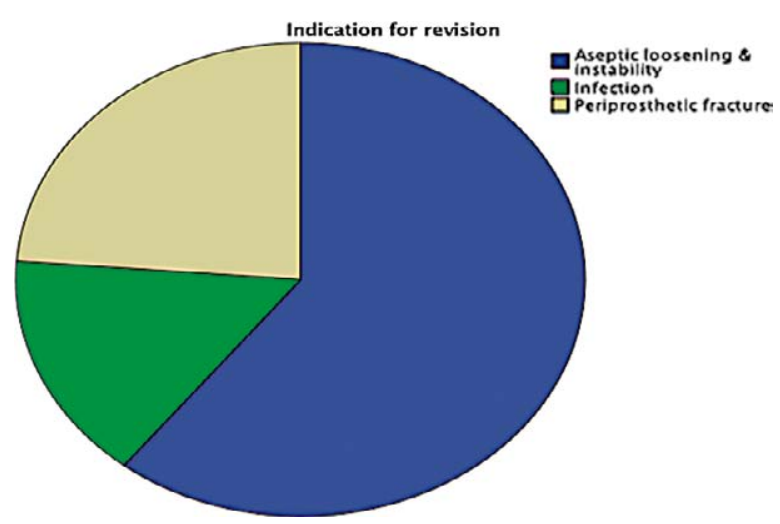

Fig. 1. Distribution of indications for revision total hip arthroplasty.

Total cost of treatment for aseptic loosening and instability, infection and periprosthetic fracture is shown in Table 1. Health insurance reimbursements for aseptic loosening and instability, infection and
Table 1. Total cost of treatment for aseptic loosening and instability, infection and periprosthetic fracture

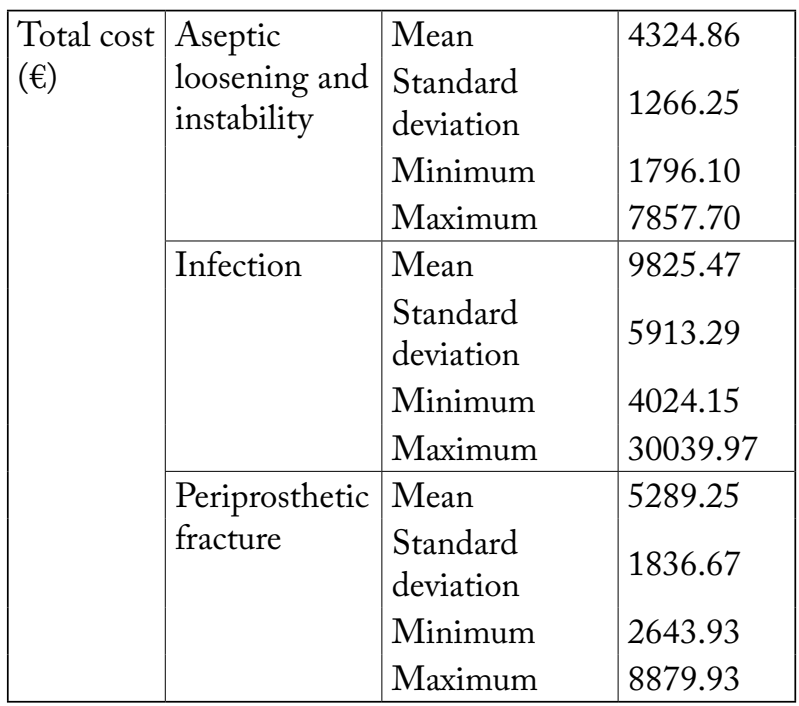

Table 2. Health insurance reimbursements for aseptic loosening and instability, infection and periprosthetic fracture

\begin{tabular}{|c|c|c|c|}
\hline \multirow[t]{4}{*}{$\begin{array}{l}\text { Health } \\
\text { insurance } \\
\text { reimbursement } \\
(€)\end{array}$} & $\begin{array}{l}\text { Aseptic } \\
\text { loosening } \\
\text { and instability }\end{array}$ & \begin{tabular}{|l} 
Mean \\
Standard \\
deviation \\
Minimum \\
Maximum
\end{tabular} & $\begin{array}{l}4062.03 \\
1056.89 \\
3190.00 \\
8050.00\end{array}$ \\
\hline & Infection & Mean & 8130.52 \\
\hline & & $\begin{array}{l}\text { Standard } \\
\text { deviation } \\
\text { Minimum } \\
\text { Maximum }\end{array}$ & $\begin{array}{l}5184.03 \\
3190.00 \\
24820.00\end{array}$ \\
\hline & $\begin{array}{l}\text { Periprosthetic } \\
\text { fracture }\end{array}$ & $\begin{array}{l}\text { Mean } \\
\text { Standard } \\
\text { deviation } \\
\text { Minimum } \\
\text { Maximum }\end{array}$ & $\begin{array}{l}4372.76 \\
824.30 \\
3190.00 \\
5760.00\end{array}$ \\
\hline
\end{tabular}

periprosthetic fracture is shown in Table 2. The cost of implants for aseptic loosening and instability, infection and periprosthetic fracture is shown in Table 3 . The mean total cost was significantly higher for those undergoing revision for infection (9825.47 €; SD 5913.29) than in the aseptic loosening and instability group (4324.86 €; SD 1266.25; p<0.001, unpaired $\mathrm{t}$-test). The mean total cost was significantly higher for those undergoing revision for infection (9825.47 €; 
Table 3. Cost of implants for aseptic loosening and instability, infection and periprosthetic fracture

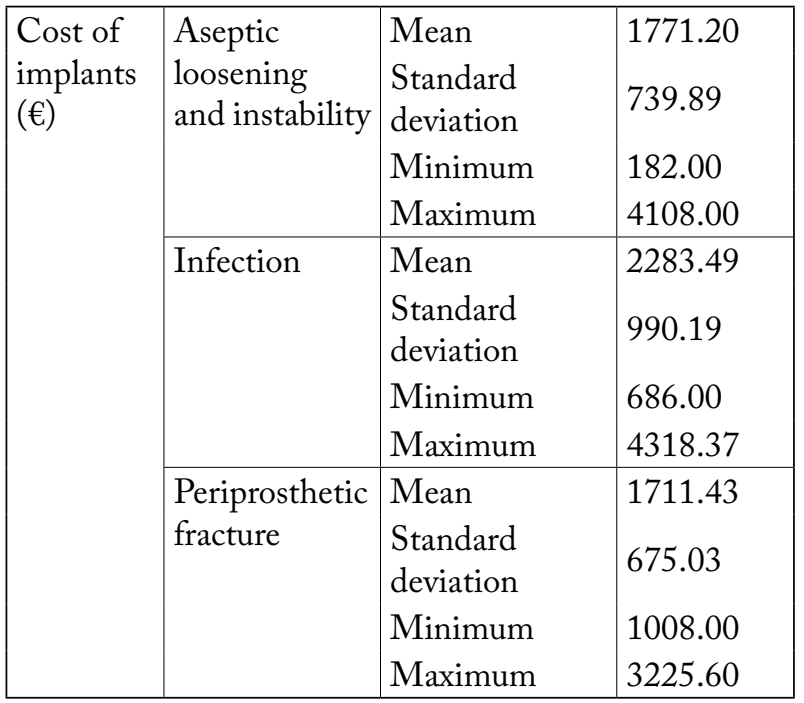

Table 4. Length of hospital stay for aseptic loosening and instability, infection and periprosthetic fracture

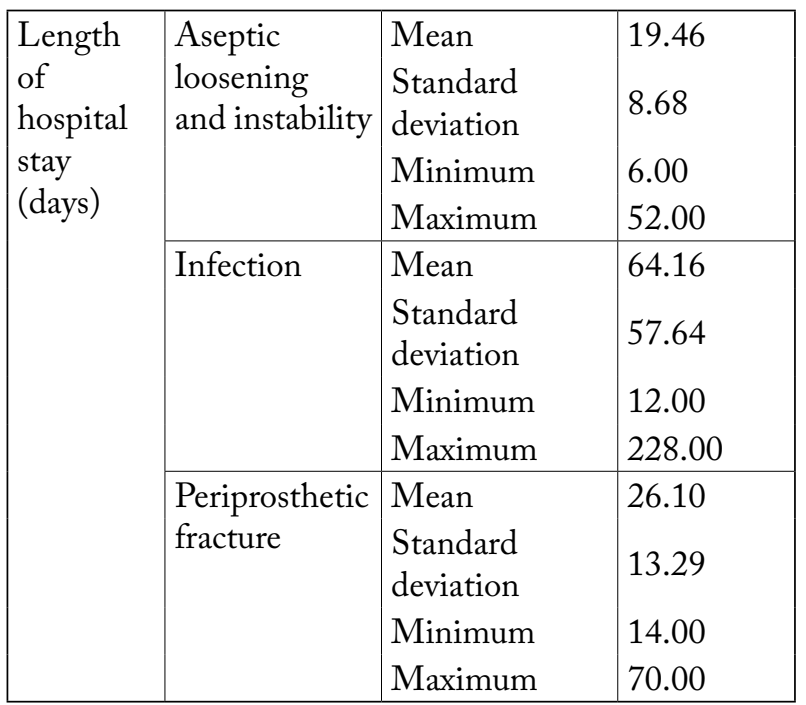

SD 5913.29) than in the periprosthetic fracture group (5289.25 €; SD 1836.67; p<0.004, unpaired t-test). The mean total cost was significantly higher for those undergoing revision for periprosthetic fracture (5289.25 €; SD 1836.67) than in the aseptic loosening and instability group (4324.86 €; SD 1266.25; $<<0.013$, unpaired t-test). The length of hospital stay (in days) for aseptic loosening and instability, infection and periprosthetic fracture is shown in Table 4. Financial analysis of revision hip arthroplasty for aseptic loosening and instability, infection and periprosthetic fracture is shown in Table 5.

\section{Discussion}

In the USA, an estimated 2.5 million people are living with hip replacement ${ }^{9}$. Revision THA is a complex procedure that is associated with a greater risk for patients and greater cost for the treating hospital when compared with primary THA. Revised procedures for periprosthetic joint infection (PJI) are associated with a significantly higher number of hospitalizations, hospital days and number of operations, as well as longer operating time, more blood loss, prolonged antibiotic therapy, higher number of radiographic examinations, and more total outpatient visits during 12 -month period following the index procedure. Complications will become an accruing burden to the health care system in the next two decades ${ }^{10-13}$. The economic impact of PJI is significant. The overall cost to the American health care system to treat PJI was 566 million dollars in 2009, a number that is projected to reach 1.62 billion dollars in $2020^{14}$.

In some national health insurance systems, institutions do not recognize this problem. For example, a study undertaken in Germany ${ }^{8}$ found that reimbursement was inadequate. In this study, a total of 281 patients were treated in 2015 due to infection of the

Table 5. Financial analysis of revision hip arthroplasty for aseptic loosening and instability, infection and periprosthetic fracture

\begin{tabular}{|l|l|l|l|}
\hline & Mean total cost $(€)$ & $\begin{array}{l}\text { Mean health insurance } \\
\text { reimbursement }(€)\end{array}$ & Deficit $(€)$ \\
\hline Aseptic loosening and instability & 4324.86 & 4062.03 & $-262.83(-6.08 \%)$ \\
Infection & 9825.47 & 8130.53 & $-1694.94(-17.25 \%)$ \\
Periprosthetic fracture & 5289.25 & 4372.76 & $-916.49(-17.33 \%)$ \\
\hline
\end{tabular}


musculoskeletal system. Of these, 144 patients had periprosthetic infection of the knee or hip joint. Total cost of these 281 treatments was 3.3 million $€$ but only 2.7 million were covered by the diagnosis-related groups (DRG) revenues (underpaid by approximately 20\%). This corresponded to a deficit of $633,000 €$, with a mean deficit per treatment case of $2300 €$. The deficit for infected THA was about $8500 €$ on average and was five times greater than for infected total knee arthroplasty (TKA) with $1600 €$. The main reasons for the high treatment costs were the length of hospital stay, multiple surgical interventions, and isolation treatment ${ }^{8}$.

In our study, we aimed to evaluate the economic burden of the cost of revision THAs and health insurance reimbursements, with special emphasis on the cost of treating patients with revision THA for PJIs at a university hospital in a middle-income EU country. We found that the mean total cost was significantly higher for those undergoing revision for infection as compared with the aseptic loosening and instability group $(p<0.001)$ and the periprosthetic fracture group $(p<0.004)$. In addition, the mean total cost was significantly higher for those undergoing revision for periprosthetic fracture than in the aseptic loosening and instability group $(\mathrm{p}<0.013)$.

Also, the mean cost of implants was about $1800 €$ for aseptic loosening and instability, $2300 €$ for infection and $1700 €$ for fracture. The mean length of hospital stay (in days) was 20,64 and 26 days for aseptic loosening and instability, infection and fracture, respectively. All hospitalizations and rehospitalizations were included in the study.

We compared the mean total cost and the mean Croatian Health Insurance Fund reimbursements and found the mean deficit of $260 €$ for aseptic loosening and instability, $1700 €$ for infections, and $900 €$ for periprosthetic fracture. Patients with PJI require repetitive hospitalization, more days of hospitalization, more surgical procedures and antibiotic therapy, which increases the cost of treatment as opposed to revision for aseptic instability or periprosthetic fracture. The Croatian Health Insurance Fund reimburses the same amount through the DRG system for different indications and treatment modalities in revision hip surgery and therefore the highest deficit is generated in the case of infection.

Kallala et al. ${ }^{15}$ examined inpatient hospital data on 168 revision TKAs. They found that revision surgery for infection was associated with a mean length of stay more than double that in aseptic cases. The mean cost of revision for infection was more than three times that of aseptic revision. Total reimbursement was 1.9 million $£$, yielding an average loss of 4.5 thousand $£$ per case in 168 cases $^{15}$.

Our study had several limitations. These were retrospective design and data on the costs were obtained using the hospital accounting system. Therefore, we could not obtain and differentiate (other costs) all cost data for economic analyses. We can expect that the overall cost of treatment is much higher, especially in case of infection and if the patient is active because these is only the cost of treatment at the hospital, without the cost of treatment outside hospitals, as well as the possible loss of income for the patient.

Croatia is a country with a significant share of public social health and small share of private sector. The cost of treatment in hospitals is arbitrary and is determined by the Croatian Health Insurance Directorate. So far, hospital institutions have not commented on the cost of treatment for revision interventions after THA and reimbursements from the Croatian Health Insurance Fund.

In the Croatian health system, we do not have a system where patients with these conditions are transferred to centers of excellence, to reduce treatment costs $^{8}$. There is no broader social understanding of the length and cost of treating hip revision interventions, especially for infection. Organized education of all medical professionals on the prevention of surgical infections should be introduced in the Croatian health system, as well as raising awareness of the cost of treating bone infections.

\section{References}

1. Rozell J, Donegan D. Periprosthetic femur fractures around a loose femoral stem. J Orthop Trauma. 2019 Sep;33 Suppl 6:S10-S13. doi: 10.1097/BOT.0000000000001568

2. Negus J, Gifford P, Haddad F. Single-stage revision arthroplasty for infection - an underutilized treatment strategy. J Arthroplasty. 2017 Jul;32(7):2051-5. doi: 10.1016/j.arth.2017. 02.059

3. Kenney C, Dick S, Lea J, Liu J, Ebraheim NA. A systematic review of the causes of failure of revision total hip arthroplasty. J Orthop. 2019 May 2;16(5):393-5. doi: 10.1016/j.jor.2019. 04.011 
4. Kurtz SM, Lau E, Watson H, et al. Economic burden of periprosthetic joint infection in the United States. J Arthroplasty. 2012;27(8 Suppl):S61-S65.e1 doi: 10.1016/j.arth.2012.02.022

5. Dale H, Fenstad AM, Hallan G, et al. Increasing risk of prosthetic joint infection after total hip arthroplasty. Acta Orthop. 2012;83:449-58. doi: 10.3109/17453674.2012.733918

6. Kapadia BH, McElroy MJ, Issa K, et al. The economic impact of periprosthetic infections following total knee arthroplasty at a specialized tertiary-care center. J Arthroplasty. 2014;29:92932. doi: 10.1016/j.arth.2013.09.017

7. Hernández-Vaquero D, Fernández-Fairen M, Torres A, et al. Treatment of periprosthetic infections: an economic analysis. Sci World J. 2013;2013:821650. Published 2013 May 28. doi: $10.1155 / 2013 / 821650$

8. Müller M, Trampuz A, Winkler T, Perka C. The economic challenge of centralised treatment of patients with periprosthetic infections. Z Orthop Unfall. 2018 Feb 7 doi: 10.1055/s0044-100732

9. Maradit Kremers H, Larson DR, Crowson CS, et al. Prevalence of total hip and knee replacement in the United States. J Bone Joint Surg Am. 2015;97:1386-97. doi: 10.2106/JBJS.N.01141

10. Wolf CF, Gu NY, Doctor JN, Manner PA, Leopold SS. Comparison of one and two-stage revision of total hip arthroplasty complicated by infection: a Markov expected-utility decision analysis. J Bone Joint Surg Am. 2011 Apr 6;93(7):631-9. doi: 10.2106/JBJS.I.01256

11. Parvizi J, Pawasarat IM, Azzam KA, Joshi A, Hansen EN, Bozic KJ. Periprosthetic joint infection: the economic impact of methicillin-resistant infections. J Arthroplasty. 2010 Sep;25(6 Suppl):103-7. doi: 10.1016/j.arth.2010.04.011

12. Berend KR, Lombardi AV Jr, Morris MJ, Bergeson AG, Adams JB, Sneller MA. Two-stage treatment of hip periprosthetic joint infection is associated with a high rate of infection control but high mortality. Clin Orthop Relat Res. 2013 Feb;471 (2):510-8. doi: 10.1007/s11999-012-2595-x

13. Kurtz S, Ong K, Lau E, Mowat F, Halpern M. Projections of primary and revision hip and knee arthroplasty in the United States from 2005 to 2030. J Bone Joint Surg Am. 2007 Apr;89(4):780-5. doi: 10.2106/JBJS.F.00222

14. Tande AJ, Patel R. Prosthetic joint infection. Clin Microbiol Rev. 2014 Apr;27(2):302-45. doi: 10.1128/CMR.00111-13

15. Kallala RF, Vanhegan IS, Ibrahim MS, Sarmah S, Haddad FS. Financial analysis of revision knee surgery based on NHS tariffs and hospital costs: does it pay to provide a revision service? Bone Joint J. 2015 Feb;97-B(2):197-201. doi: 10.1302/0301620X.97B2.33707

\section{Sažetak \\ HRVATSKI FOND ZA ZDRAVSTVENO OSIGURANJE NE PREPOZNAJE RAZLIKE UTROŠKOVIMA RAZLIČITIH MODALITETA REVIZIJE TOTALNE ARTROPLASTIKE KUKA}

\section{S. Sabalić, D. Vidović, S. Babić, T. Ćuti, D. Gajski, K. Rotim i D. Blažević}

Posljednjih godina sve je veći interes za troškove liječenja revizijskih intervencija kod endoproteza kuka i koljena. U svim dosadašnjim publikacijama autori bilježe visoke troškove liječenja revizijskih intervencija, osobito ako je prisutna infekcija. Cilj ove studije bio je usporediti troškove liječenja i naknade zdravstvenog osiguranja između revizije totalne artroplastike kuka za infekciju i revizije za aseptične indikacije (aseptična nestabilnost i periprotetski prijelom). Analizirani su bolnički podaci 168 bolesnika koji su bili podvrgnuti reviziji totalne artroplastike kuka u razdoblju od 2010. do 2018. godine na Klinici za traumatologiju Kliničkog bolničkog centra Sestre milosrdnice u Zagrebu. Financijski podaci prikupljeni su iz bolničkog informacijskog sustava. Financijska analiza uključivala je ukupni trošak po bolesniku, troškove hrvatskog zdravstvenog osiguranja, troškove implantata i duljinu boravka u bolnici. Razlika između srednje vrijednosti ukupnog troška po bolesniku i srednje vrijednosti povrata hrvatskog zdravstvenog osiguranja bila je $-262,83 €(-6,08 \%)$ za aseptičnu nestabilnost, $-1694,94$ $€(-17,25 \%)$ za infekciju i $-916,49 €(-17,33 \%)$ za periprotetski prijelom. Hrvatski fond za zdravstveno osiguranje ne prepoznaje razlike u troškovima revizije totalne endoproteze kuka za aseptičnu nestabilnost, infekciju i periprotetski prijelom. Naknada za zdravstveno osiguranje nije odgovarajuća za centre koji obavljaju reviziju kuka.

Ključne riječi: Revizija totalne artroplastike kuka; Infekcija; Periprotetski prijelom; Aseptična nestabilnost; Financijska analiza 